\title{
Penggunaan Polimer Golongan Polisakarida untuk Enkapsulasi Zat Aktif dengan Perbedaan Sifat Keasaman
}

\author{
Siska Sari Marvita*,1, Anis Yohana Chaerunisaa², Dolih Gozali ${ }^{2}$ \\ ${ }^{1}$ Program Studi Magister Farmasi, Fakultas Farmasi, Universitas Padjajaran, Jl. Raya \\ Bandung-Sumedang KM 21 Jatinangor 45363, Jawa Barat, Indonesia \\ 2Departemen Farmasetika dan Teknologi Farmasi, Fakultas Farmasi, Universitas Padjajaran, \\ Jl. Raya Bandung-Sumedang KM 21 Jatinangor 45363, Jawa Barat, Indonesia \\ *E-mail: siska20005@mail.unpad.ac.id \\ (Submit 15/4/2021, Revisi 11/5/2021, Diterima 16/5/2021, Terbit 25/5/2021)
}

\begin{abstract}
Abstrak
Obat merupakan zat aktif yang bersifat asam atau basa. Beberapa zat aktif memiliki stabilitas yang rendah dan pelepasan obat yang kurang terkontrol. Masalah ini dapat diatasi dengan mengenkapsulasi zat aktif tersebut menggunakan polimer bersifat biodegradable, salah satunya polimer golongan polisakarida yang telah banyak digunakan seperti alginat, kitosan, pektin, dan selulosa. Enkapsulasi zat aktif telah menghasilkan banyak sifat penting seperti penghantaran obat lepas lambat atau terkontrol, peningkatan stabilitas, dan peningkatan bioavailabilitas sehingga dapat meningkatkan kesesuaian untuk aplikasinya. Artikel ini dibuat dengan menggunakan metode pencarian referensi secara online yang berasal dari free database "sciencedirect.com" dari tahun 2012 - 2021. Artikel ini akan membahas beberapa penggunaan polimer golongan polisakarida untuk ekapsulasi zat aktif dengan perbedaan sifat keasaman. Berdasarkan beberapa data penelitian yang terkumpul, membuktikan keberhasilan polimer polisakarida dalam mengenkapsulasi zat aktif yang bersifat asam dan basa. Parameter keberhasilan yang dinilai dalam artikel ini untuk enkapsulasi zat aktif adalah nilai efisiensi enkapsulasi dan pelepasan obat. Zat aktif yang bersifat asam cenderung memiliki efisiensi enkapsulasi yang lebih tinggi daripada zat aktif bersifat basa. Namun, tidak memberikan perbedaan pelepasan obat pada kondisi cairan lambung dan cairan usus. Zat aktif dengan sifat keasaman yang berbeda sama-sama memiliki pelepasan obat tertinggi pada kondisi basa.
\end{abstract}

Kata kunci: Alginat, enkapsulasi zat aktif, kitosan, pektin, selulosa 


\section{Pendahuluan}

Industri farmasi memiliki tanggungjawab untuk terus mengembangkan dan meningkatkan kualitas obat yang akan dipasarkan secara global. Umumnya, obat yang beredar di pasaran mengandung zat aktif bersifat asam misalnya amoksillin, vankomisin, asam folat, dan asam askorbat, atau bersifat basa misalnya teofilin, amikasin, natrium diklofenak, dan sebagainya ${ }^{[1]}$. Beberapa zat aktif tersebut memiliki stabilitas yang rendah dan pelepasan obat yang kurang terkontrol, seperti asam folat yang mudah terdegradasi dalam kondisi asam ${ }^{[2]}$, asam askorbat yang sensitif terhadap suhu dan oksigen yang menyebabkannya mudah terdegradasi ${ }^{[3,4]}$, dan teofilin yang memerlukan perpanjangan pelepasan obat ${ }^{[5]}$. Hal ini mendorong perkembangan dan peningkatan stabilitas zat aktif untuk menghasilkan kualitas obat yang lebih baik. Salah satu peningkatan stabilitas zat aktif yang telah banyak dilakukan yaitu dengan teknik enkapsulasi.

Enkapsulasi adalah teknik penyalutan zat aktif dalam matriks polimer untuk meningkatkan stabilitas, sehingga lebih stabil daripada bentuk bebasnya dan untuk meningkatkan bioavailabilitas zat aktifi[]. Polimer yang banyak digunakan bersifat biodegradable, baik dari polimer alami maupun sintesis ${ }^{[7]}$. Salah satu jenis polimer alami yang sering digunakan yaitu berasal dari golongan polisakarida, seperti kitosan, selulosa, pektin, dan alginat ${ }^{[8-17]}$.

Polisakarida adalah karbohidrat besar yang cukup beragam yang dapat terdiri dari hanya satu jenis monosakarida berulang (homopolisakarida atau homoglikan); misalnya pati dan selulosa, atau dibentuk oleh dua/lebih unit monomer yang berbeda (heteropolisakarida atau heteroglikan); misalnya kitosan, Pektin, alginat, dan karagenan ${ }^{[18]}$. Polimer karbohidrat menunjukkan sifat biokompatibilitas, biodegradabilitas, kelimpahan relatif tinggi dan biaya rendah, sehingga menjadikan mereka sangat diperlukan sebagai matriks untuk pembawa zat aktif dan menjaga kestabilan zat aktif ${ }^{[8]}$. Faktanya, zat aktif bersifat asam atau basa telah dienkapsulasi dengan sejumlah polimer karbohidrat, khususnya polisakarida, seperti asam folat, asam askorbat dan vankomisin dienkapsulasi dengan kitosan ${ }^{[11]}$, alginat ${ }^{[3,6]}$, alginat-pektin ${ }^{[8]}$, selulosa-kitosan ${ }^{[4,9,19]}$, dan kitosan-alginat ${ }^{[10]}$, serta natrium diklofenak dan Klotrimazol dienkapsulasi dengan kitosan ${ }^{[20-22]}$, pektin ${ }^{[16]}$, dan selulosa-kitosan ${ }^{[23]}$.

Faktor yang dapat mempengaruhi enkapsulasi adalah konsentrasi polimer dan interaksi kimia (seperti ikatan sambung silang antarpolimer) selama proses enkapsulasi[22,24]. Selain itu, sifat zat aktif juga dapat mempengaruhi enkapsulasi, seperti sifat asam dan basa zat aktif memberikan pengaruh terhadap efisiensi enkapsulasi dan pelepasan obat. Zat aktif yang bersifat asam cenderung memiliki nilai efisiensi enkpsulasi lebih tinggi daripada zat aktif yang bersifat basa. Seperti telah dilaporkan oleh Khan dkk (2021), efisiensi enkapsulasi zat aktif bersifat asam (amoksillin, vankomisin, dan Siproloksasin) dengan kitosan-alginat mencapai 91 - 95\% ${ }^{[10]}$. Enkapsulasi teofilin (bersifat basa) dengan alginat mencapai $72,25 \%{ }^{[5]}$ dan kitosan mencapai 41,6 $70,45 \%{ }^{[15]}$. 
Tujuan dari penulisan artikel review ini adalah untuk memberikan informasi penggunaan polimer golongan polisakarida dalam enkapsulasi zat aktif, serta perbedaan sifat keasaman zat aktif yang mempengaruhi efisiensi enkapsulasi dan pelepasan obat. Karena sejauh ini belum diketahui adanya informasi mengenai pengaruh $\mathrm{pH}$ dari zat aktif terhadap hasil enkapsulasi.

\section{Metode}

Sumber referensi yang digunakan dalam review artikel ini diperoleh dengan menggunakan free database "sciencedirect.com" dari tahun 2012 - 2021 dalam kategori research articles dengan kata kunci "folic acid encapsulation", "ascorbic acid encapsulation", "amoxicillin encapsulation", "vancomycin encapsulation", "ciprofloxacin encapsulation", "paracetamol encapsulation", "cephalexin encapsulation" "thiamine encapsulation" "meropenem encapsulation", "doxycycline encapsulation", "theophylline encapsulation", "clotrimazole encapsulation", dan "diclofenac sodium encapsulation". Kriteria eksklusi dalam artikel ini adalah jurnal yang tidak termasuk enkapsulasi menggunakan polimer golongan polisakarida, serta jurnal yang tidak membahas tentang efisiensi enkapsulasi/drug loading. Diagram alir dalam literatur dapat dilihat pada Gambar 1.

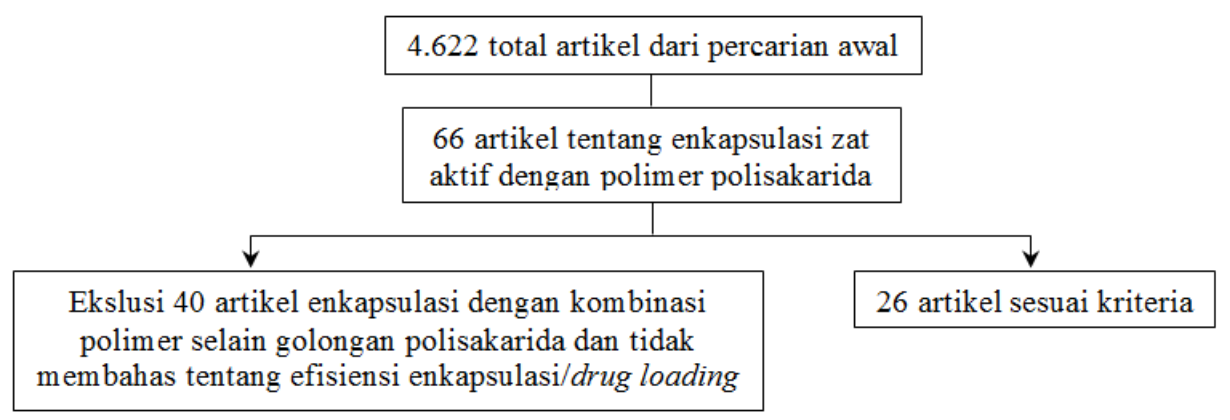

Gambar 1. Diagram alir pencarian literatur.

\section{Efektivitas Enkapsulasi dari Polimer Polisakarida}

Polimer alami yang berasal dari golongan polisakarida mendapatkan perhatian dari peneliti untuk dikembangkan dalam bidang farmasi untuk enkapsulasi zat aktifi[25], karena sifat umumnya yang toksisitas rendah, biokompatibilitas yang baik dan biodegradable ${ }^{[16]}$. Polimer polisakarida yang umum digunakan yaitu kitosan, alginat, selulosa, dan pektin. Polimer-polimer tersebut telah banyak digunakan untuk enkapsulasi zat aktif yang bersifat asam maupun basa (dapat dilihat pada Tabel 1).

Salah satu parameter keberhasilan dari proses enkapsulasi adalah berdasarkan uji efisiensi enkapsulasi, yang menunjukkan berapa persen zat aktif berhasil terenkapsulasi oleh polimer. Oleh karena itu, nilai efisiensi enkapsulasi merupakan salah satu parameter yang menunjukkan keberhasilan atau efektivitas dari polimer polisakarida untuk enkapsulasi suatu zat aktif. Berdasarkan Tabel 2 dan 3, jenis polimer golongan polisakarida yang banyak digunakan adalah alginat, kitosan, selulosa, pektin, dan turunannya. Enkapsulasi zat aktif dengan polimer-polimer tersebut dilakukan 
Tabel 1. Aplikasi polimer golongan polisakarida untuk enkapsulasi zat aktif






\begin{tabular}{|c|c|c|c|c|c|c|c|}
\hline $\begin{array}{c}\text { Polimer } \\
\text { polisakarida }\end{array}$ & Zat aktif & & Pre-formulasi & Formulasi & Evaluasi & Karakterisasi & Ref. \\
\hline & $\begin{array}{l}\text { Klotrimazol } \\
(\mathrm{KZ})\end{array}$ & $\begin{array}{l}- \\
-\end{array}$ & $\begin{array}{l}\text { KZ 0,5 mg } \\
\text { CS 25, 50, } 75 \text {, } \\
\text { dan } 100 \mathrm{~g}\end{array}$ & $\begin{array}{ll}- & \mathrm{KZZ/CS} 2 \\
- & \mathrm{KZ} / \mathrm{CS} 5 \\
- & \mathrm{KZ} / \mathrm{CS} 75 \\
- & \mathrm{KZ} / \mathrm{CS} 100\end{array}$ & $\begin{array}{l}\text { Efisiensi enkapsulasi } \\
\text { dan pelepasan obat. }\end{array}$ & $\begin{array}{l}\text { FTIR, SEM, } \\
\text { dan PSA. }\end{array}$ & [21] \\
\hline & $\begin{array}{l}\text { Natrium } \\
\text { diklofenak } \\
\text { (ND) }\end{array}$ & $\begin{array}{l}- \\
-\end{array}$ & $\begin{array}{l}\text { CS BM rendah } 5 \\
\mathrm{mg} / \mathrm{mL} \\
\mathrm{CS} \mathrm{BM} \text { tinggi } 5 \\
\mathrm{mg} / \mathrm{mL} \\
\mathrm{ND} 150 \mathrm{mg}\end{array}$ & $\begin{array}{ll}- & \mathrm{ND} / \mathrm{CS}_{\mathrm{BM}}- \\
& \text { rendah } \\
-\quad \mathrm{ND} / \mathrm{CS}_{\mathrm{BM}-} & \\
& \text { tinggi }\end{array}$ & $\begin{array}{l}\text { Efisiensi enkapsulasi, } \\
\text { Pelepasan obat, dan } \\
\text { kinetika pelepasan. }\end{array}$ & $\begin{array}{l}\text { TEM dan } \\
\text { PSA. }\end{array}$ & [20] \\
\hline & $\begin{array}{l}\text { Meropenem } \\
(\mathrm{MP})\end{array}$ & $\begin{array}{l}- \\
-\end{array}$ & $\begin{array}{l}\text { MP } 3,5 \mathrm{mg} \\
\text { Rasio berat } \\
\text { CS:TPP 3:1, 5:1, } \\
\text { dan 9:1 }\end{array}$ & $\begin{array}{ll}- & \text { MP/CS- } \\
& \text { TPP3:1 } \\
-\quad & \text { MP/CS- } \\
& \text { TPP5:1 } \\
-\quad & \text { MP/CS- } \\
& \text { TPP9:1 }\end{array}$ & $\begin{array}{l}\text { Efisiensi enkapsulasi, } \\
\text { drug loading, } \\
\text { pelepasan obat dan } \\
\text { aktivitas antibakteri. }\end{array}$ & $\begin{array}{l}\text { TEM, XRD, } \\
\text { FTIR, dan } \\
\text { PSA. }\end{array}$ & [30] \\
\hline $\begin{array}{l}\text { Alginat - } \\
\text { pektin }\end{array}$ & $\begin{array}{l}\text { Asam folat } \\
\text { (AF) }\end{array}$ & $\begin{array}{l}- \\
- \\
-\end{array}$ & $\begin{array}{l}\text { AL } 30 \% \mathrm{w} \\
\text { PK } 70 \% \mathrm{w} \\
\text { AF } 10 \mathrm{mg}\end{array}$ & AF/AL-PK3:7 & $\begin{array}{l}\text { Efisiensi enkapsulasi, } \\
\text { drug loading, dan } \\
\text { pelepasan obat. }\end{array}$ & $\begin{array}{l}\text { FTIR, SEM, } \\
\text { dan PSA. }\end{array}$ & [8] \\
\hline $\begin{array}{l}\text { Kitosan - } \\
\text { xanthan gum }\end{array}$ & $\begin{array}{l}\text { Siprofloksasin } \\
\text { (SP) }\end{array}$ & $\begin{array}{l}- \\
-\end{array}$ & $\begin{array}{l}\text { SP } 250 \mu \mathrm{g} / \mathrm{mL} \\
\text { N-trimetil kitosan } \\
\text { (TCS) } 0,5 \\
\text { g/50mL } \\
\text { Natrium } \\
\text { karboksilmetil } \\
\text { xanthan gum } \\
\text { (CMXG) } 0,5 \\
\text { g/50mL }\end{array}$ & $\begin{array}{l}\text { SP/TCS- } \\
\text { CMXG }\end{array}$ & $\begin{array}{l}\text { Efisiensi enkapsulasi, } \\
\text { drug loading, swelling, } \\
\text { aktivitas antimikroba, } \\
\text { dan toksisitas. }\end{array}$ & $\begin{array}{l}\text { FTIR, NMR, } \\
\text { DSC, dan } \\
\text { SEM. }\end{array}$ & [25] \\
\hline \multirow[t]{4}{*}{$\begin{array}{l}\text { Kitosan - } \\
\text { alginat }\end{array}$} & $\begin{array}{l}\text { Amoksisilin } \\
(\mathrm{AM}), \\
\text { siprofloksasin } \\
(\mathrm{SP}), \text { dan } \\
\text { vankomisin } \\
(\mathrm{VN})\end{array}$ & $\begin{array}{l}- \\
- \\
-\end{array}$ & $\begin{array}{l}\text { CS } 20 \mathrm{mg} / \mathrm{mL} \\
\text { AL } 10 \mathrm{mg} / \mathrm{mL} \\
\text { Antibiotik: } \\
\text { AM } 5 \mathrm{mg} / \mathrm{mL}, \mathrm{VN} \\
5 \mathrm{mg} / \mathrm{mL} \text {, dan SP } \\
5 \mathrm{mg} / \mathrm{mL} .\end{array}$ & $\begin{array}{l}\text { CS-AL/ } \\
\text { campuran } \\
\text { antibiotik }(20: 1 \\
\text { mg) }\end{array}$ & $\begin{array}{l}\text { Efisiensi enkapsulasi, } \\
\text { swelling, pelepasan } \\
\text { obat, kinetika } \\
\text { pelepasan, aktivitas } \\
\text { antibakteri, dan } \\
\text { toksisitas. }\end{array}$ & SEM & [10] \\
\hline & $\begin{array}{l}\text { Klotrimazol } \\
(\mathrm{KZ})\end{array}$ & $\begin{array}{l}- \\
-\end{array}$ & $\begin{array}{l}\mathrm{KZ} 0,5 \mathrm{mg} \\
\mathrm{CS} 25,50,75 \\
\text { dan } 100 \mathrm{~g}\end{array}$ & $\begin{array}{ll}- & \mathrm{KZZ/CS} 2 \\
- & \mathrm{KZ} / \mathrm{CS} 5 \\
- & \mathrm{KZ} / \mathrm{CS} 75 \\
- & \mathrm{KZ} / \mathrm{CS} 100\end{array}$ & $\begin{array}{l}\text { Efisiensi enkapsulasi } \\
\text { dan pelepasan obat. }\end{array}$ & $\begin{array}{l}\text { FTIR, SEM, } \\
\text { dan PSA. }\end{array}$ & [21] \\
\hline & $\begin{array}{l}\text { Parasetamol } \\
\text { (PS) }\end{array}$ & - & $\begin{array}{l}\mathrm{PS} 1,5 \% \mathrm{w} / \mathrm{v} \\
\mathrm{AL} 2 \% \mathrm{w} / \mathrm{v}+ \\
\mathrm{CaCl}_{2} 1 \% \mathrm{w} / \mathrm{v} \\
\mathrm{CS} \mathrm{BM} \mathrm{rendah} \\
0,3 \% \mathrm{w} / \mathrm{v}+ \\
\mathrm{CaCl}_{2} 10 \% \mathrm{w} / \mathrm{v} \\
\mathrm{CS} \mathrm{BM} \text { tinggi } 0,3 \\
\% \mathrm{w} / \mathrm{v}+\mathrm{CaCl}_{2} \\
10 \% \mathrm{w} / \mathrm{v}\end{array}$ & 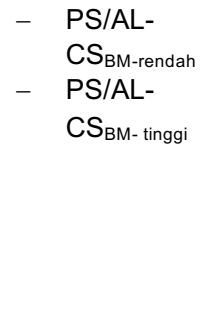 & $\begin{array}{l}\text { Efisiensi enkapsulasi, } \\
\text { pelepasan obat, dan } \\
\text { kinetika pelepasan. }\end{array}$ & $\begin{array}{l}\text { SEM, DSC, } \\
\text { dan FTIR. }\end{array}$ & [12] \\
\hline & $\begin{array}{l}\text { Amoksisilin } \\
\text { (AM) }\end{array}$ & $\begin{array}{l}- \\
-\end{array}$ & $\begin{array}{l}\text { AM } 10 \% \text { w/w } \\
\text { AL } 60 \text { dan } 80 \\
\% \text { w/w } \\
\text { CS } 1 \% \text { w/w } \\
\text { Magnesium } \\
\text { aluminium silikat } \\
\text { (MAS) } 5 \text { dan } 10 \\
\% \text { w/w } \\
\text { Natrium } \\
\text { karboksilmetil } \\
\text { selulosa } \\
\text { (NaCMC) } 20 \text { dan } \\
40 \% \text { w/w }\end{array}$ & $\begin{aligned} &- \text { AM/CS- } \\
& \text { AL80- } \\
& \text { MAS10- } \\
& \text { NaCMC20 } \\
&-\quad \text { AM/CS- } \\
& \text { AL60- } \\
& \text { MAS5- } \\
& \text { NaCMC40. }\end{aligned}$ & $\begin{array}{l}\text { Efisiensi enkapsulasi, } \\
\text { drug loading, } \\
\text { pelepasan obat, dan } \\
\text { swelling. }\end{array}$ & $\begin{array}{l}\text { FTIR, DSC, } \\
\text { XRD, SEM, } \\
\text { dan PSA. }\end{array}$ & [33] \\
\hline
\end{tabular}




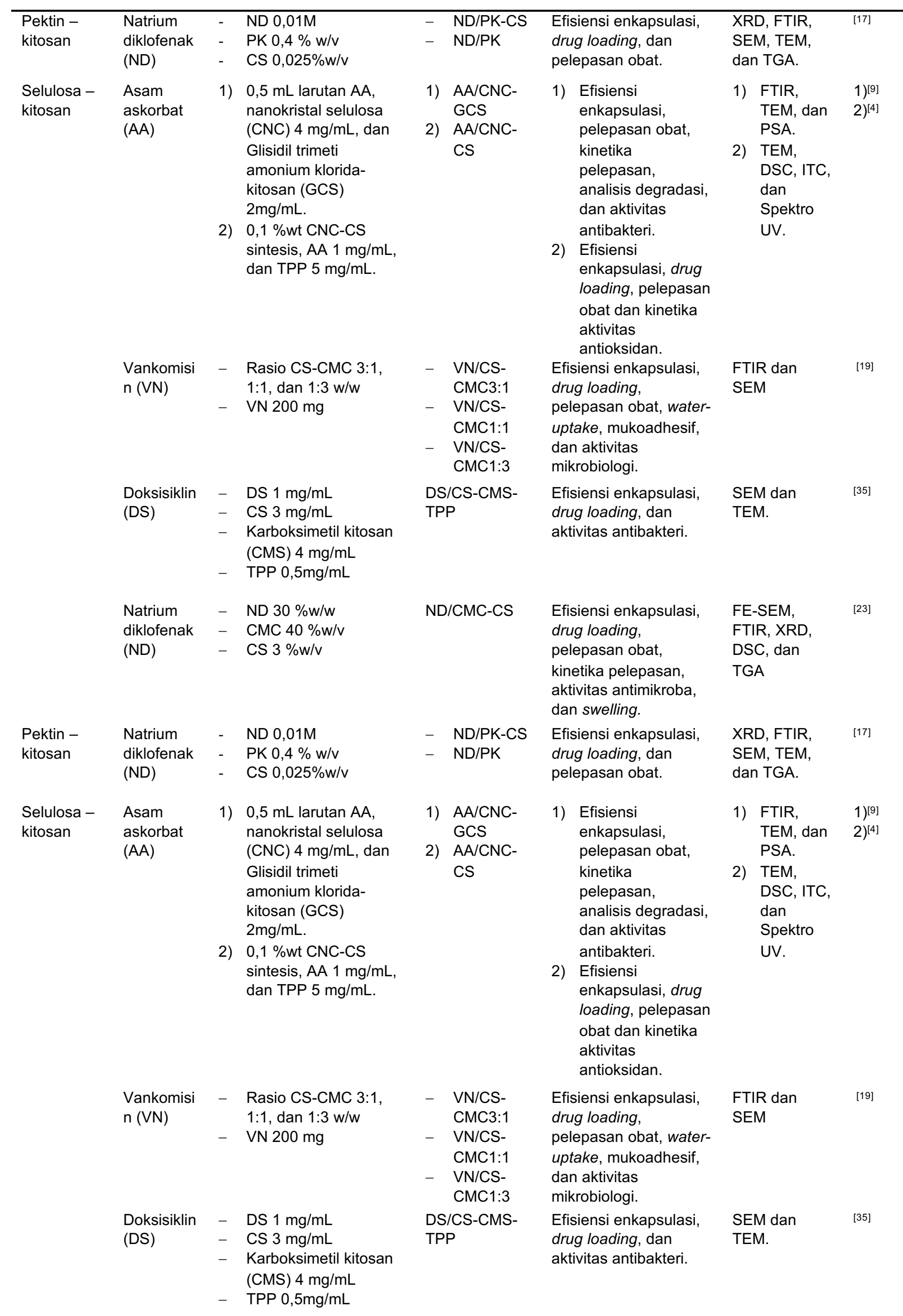


dengan/tanpa kombinasi polimer, serta sejauh ini tidak ada pemilihan khusus untuk jenis polimer polisakarida yang digunakan untuk enkapsulasi zat aktif yang bersifat asam maupun basa. Semua jenis polimer polisakarida tersebut berhasil mengenkapsulasi zat aktif bersifat asam maupun basa dengan nilai efesiensi enkapsulasi yang berbeda. Perbedaan ini dipengaruhi oleh konsentrasi polimer yang digunakan, serta beberapa faktor lainnya seperti kondisi $\mathrm{pH}$, ukuran partikel, dan interaksi antarpolimer atau polimer dengan zat aktif. Rata-rata nilai efisiensi enkapsulasi yang dihasilnya berdasarkan pengamatan Tabel 2 dan 3 mencapai sekitar $70 \%$, serta penggunaan kombinasi polimer memberikan efektivitas enkapsulasi lebih baik daripada tanpa adanya kombinasi ${ }^{[8,10,24]}$, karena dapat melengkapi kekurangan dari masingmasing polimer. Secara umum, jenis polimer yang baik digunakan untuk enkapsulasi zat aktif antara lain :

a. Harus kompatibel secara kimiawi,

b. Tidak reaktif dengan zat aktif, dan

c. Memberikan stabilitas dan pelepasan zat aktif yang baik.

\section{Kitosan}

Kitosan adalah polisakarida polikationik linear yang diperoleh dari N-deasetilasi kitin, yang terdiri dari monomer $\mathrm{N}$-asetilglukosamin dan $\mathrm{D}$-glukosamin yang dihubungkan oleh ikatan $\beta-1,4$-glikosidik ${ }^{[26-29]}$. Kitosan menunjukkan sifat yang menarik seperti nontoksisitas, biokompatibiltas, biodegradabilitas enzimatik, mukoadhesif yang baik, sensitifitas $\mathrm{pH}$, polikationik, dan antibakteri ${ }^{[26,30,31]}$, sehingga banyak digunakan untuk aplikasi biomedis seperti rekayasa jaringan, sistem penghantaran obat, meningkatkan bioavabilitas obat, dan lain-lain ${ }^{[19,25,28]}$. Namun, kitosan memiliki kelarutan yang rendah pada $\mathrm{pH}$ diatas 6,5 , karena gugus amina kitosan memiliki nilai pKa sekitar 6,5 dan pada kondisi ini dapat mengalami deprotonas $i^{[9,32]}$, sehingga membatasi penggunaanya untuk penghantaran obat yang terkontrol ${ }^{[25,31]}$. Hal ini dapat diatasi dengan memodifikasi kitosan secara kimia melalui ikatan silang kovalen atau ionik, dan pembentukan komplek polielektrolit dari gugus amina yang bermutan positif dengan gugus anionik dari polimer lain ${ }^{[19,31]}$, seperti pembentukan komplek polielektrolit dari gugus amina pada kitosan dengan gugus karboksil pada karboksimetil selulosa dalam media asam ${ }^{[19]}$. Beberapa polimer dari golongan polisakarida yang sering digunakan untuk modifikasi kitosan yaitu alginat ${ }^{[10,12,33]}$ pektin ${ }^{[17]}$, dan selulosa ${ }^{[9,19,23]}$. Selain itu, aplikasi kitosan juga tidak terbatas pada turunannya, seperti $\mathrm{N}$-suksinil kiotsan ${ }^{[32,34]}$, N-trimetil kitosan $^{[25]}$, dan karboksimetil kitosan ${ }^{[35]}$.

Aplikasi kitosan dalam penghantaran obat salah satunya melalui enkapsulasi zat aktif. Beberapa zat aktif yang telah berhasil dienkapsulasi oleh kitosan dan modifikasinya disajikan pada Tabel 2 dan 3. Kitosan Berdasarkan berat molekulnya (BM), kitosan dikategorikan menjadi berat molekul rendah ( $<50 \mathrm{kDa})$, BM sedang $(50-150 \mathrm{kDa})$, dan BM tinggi $(>150 \mathrm{kDa})^{[20]}$. BM kitosan dapat mempengaruhi nilai efisiensi enkapsulasi, kitosan dengan BM tinggi akan meningkatkan nilai efisiensi enkapsulasi dan drug loading, karena rantai kitosan yang lebih panjang ${ }^{[12,20,36]}$. Selain itu, faktor lain yang mempengaruhi enkapsulasi adalah konsentrasi polimer dan ikatan silang selama proses enkapsulasi[22,24], seperti kitosan untuk enkapsulasi klotrimazol menunjukkan efisiensi yang lebih tinggi karena adanya gaya tarik elektrostastik antara gugus $\mathrm{NH}_{3}{ }^{+}$kitosan 
dengan muatan negatif dari klotrimazol, dan interaksi yang terjadi juga mempengaruhi pelepasan klotrimazol yang lebih lambat ${ }^{[21]}$, karena semakin padatnya ikatan silang ${ }^{[22]}$. Kepadatan ikatan silang mengakibat ketebalan dan kekuatan membran kitosan meningkat secara signifikan pada konsentrasi yang lebih tinggi[12].

\section{Alginat}

Alginat adalah polisakarida linear hidrofilik yang dapat diekstraksi dari alga coklat seperti Macrocystis pyrifera, Ascophyllum nodosum, dan Laminaria hyperborean, atau diisolasi dari spesies bakteri seperti Azotobacter dan Pseudomonas ${ }^{[37-39]}$. Alginat tersusun oleh dua asam uronat yaitu $\alpha$-L-asam guluronat (blok $G$ ) dan $\beta$-D-asam manuronat (blok M) yang dihubungkan melalui ikatan 1,4-glikosidik ${ }^{[40-43]}$, yang merupakan suatu gugus karboksilat dari asam uronat. Muatan negatif dari gugus karboksil dapat diikat silang dengan kation divalen seperti $\mathrm{Ca}^{2+}, \mathrm{Zn}^{2+}$, dan lainlain ${ }^{[3,33,37]}$. Ikatan silang yang terjadi dapat mempengaruhi kelarutan alginat dalam air ${ }^{[38]}$. Karena sifatnya yang dapat diikat silang, alginat banyak digunakan untuk kombinasi dengan polimer lain, seperti pektin ${ }^{[8]}$ dan kitosan $^{[10,12,33]}$ dalam aplikasi dibidang farmasi dan makanan. Selain itu, sifatnya yang non-toksik, biokompatibilitas, biodegradable dan mukoadhesif, serta ketersediaannya yang luas dan biaya yang rendah juga mendukung dalam aplikasinya ${ }^{[37-42]}$.

Salah satu penggunaan alginat dalam bidang farmasi yaitu untuk enkapsulasi zat aktif, sehingga meningkatkan stabilitas dan pelepasan obat yang terkontrol. Beberapa zat aktif telah berhasil dienkapsulasi oleh alginat dengan/tanpa kombinasi polimer lain, seperti asam folat ${ }^{[8]}$, asam askorbat ${ }^{[3]}$, amoksisilin ${ }^{[10,33]}$, vankomisin dan siprofloksasin ${ }^{[10]}$, parasetamol[12], dan teofilin ${ }^{[5]}$. Enkapsulasi dengan alginat memberikan pelepasan obat yang rendah pada kondisi asam (cairan lambung) dan sebagian besar pelepasan terjadi pada kondisi basa (cairan usus halus ${ }^{[8,12]}$, seperti yang telah dilaporkan oleh Pamunuwa dkk (2020) pada studi enkapsulasi asam folat[ ${ }^{[8]}$ dan Al-kahtani dkk (2014) pada studi enkapsulasi natrium diklofenak bahwa pelepasan obat jauh lebih rendah pada $\mathrm{pH} 1,2$ dibandingkan $\mathrm{pH}$ diatas $7,4^{[42]}$. Pada $\mathrm{pH}$ rendah, alginat terprotonasi menjadi bentuk asam alginat yang tidak larut, sehingga menunjukkan sifat pembengkakan yang menjelaskan jumlah pelepasan obat yang rendah ${ }^{[41,42]}$. Selain itu, adanya interaksi ikatan hidrogen yang lebih kuat diantara gugus karboksil menghasilkan saluran lebih kecil untuk difusi obat ${ }^{[43]}$. Dalam enkapsulasi zat aktif, konsentrasi alginat berperan penting untuk meningkatkan efisiensi enkapsulasi. Meningkatnya konsentrasi alginat dapat menurunkan efisiensi enkapsulasi[ ${ }^{[43]}$.

\section{Selulosa}

Selulosa adalah polimer polisakarida dengan rantai linier dari ikatan $\beta-1,4$ yang terikat dengan unit berulang D-glukopiranosa ${ }^{[14,44]}$. Turunan selulosa yang banyak digunakan untuk enkapsulasi zat aktif yaitu nano/mikrokristal selulosa ${ }^{[4,9,14]}$ dan karboksimetil selulosa (carboxymethyl cellulose/ $\mathrm{CMC}$ ) $^{[13,19,23]}$. Selain itu, selulosa dan turunannya yang dapat terikat silang dengan polimer lain memberikan potensi yang lebih baik untuk meningkatkan efisiensi enkapsulasi zat aktif, seperti kombinasi CMC dengan kitosan 
menunjukkan interaksi elektrostatik antara gugus $\mathrm{NH}_{3}{ }^{+}$dari kitosan dengan gugus $\mathrm{COO}^{-}$dari $\mathrm{CMC}$, dan interaksi akan semakin kuat ketika konsentrasi kitosan meningkat, karena semakin banyak ikatan yang terbentuk, sehingga meningkatkan efisiensi enkapsulasi[24].

CMC adalah turunan selulosa yang diperoleh dengan mensubstitusi atom hidrogen dari cincin D-glukopiranosa dengan bagian karboksimetil[13,14,23]. Sebagai polisakarida yang larut dalam air, CMC larut dalam air dan menjadi bermuatan negatif karena disosiasi gugus karboksi|[23]. CMC memiliki potensi untuk digunakan dalam aplikasi biomedis, karena karakteristiknya yang baik seperti sensitivitas $\mathrm{pH}$, transparansi, hidrofilisitas, non-toksisitas, biokompatibilitas, dan biodegradabilitas serta sifat pembentuk gel dan filmnya ${ }^{[45,46]}$. Aplikasi CMC dalam bidang biomedis salah satunya untuk enkapsulasi zat aktif, yang dapat meningkatkan stabilitas obat dan pelepasan obat yang terkontrol. Zat aktif yang telah berhasil dienkapsulasi yaitu vankomisin ${ }^{[19]}$, sefaleksin ${ }^{[13]}$, dan natrium diklofenak $^{[23]}$. Turunan selulosa lainnya yaitu nano/mikrokristal selulosa juga telah berhasil untuk enkapsulasi zat aktif seperti asam askorbat (vitamin C ${ }^{[4,9]}$ dan sefaleksin ${ }^{[14]}$. Nano/mikrokristal selulosa diperoleh dari $\alpha$-selulosa yang dihidrolisis oleh asam. la memiliki banyak gugus hidroksil yang dapat dimodifikasi lebih lanjut untuk berbagai fungsi, serta sifatnya yang non-toksisitas, kekuatan mekanik tinggi, kepadatan rendah, luas permukaan besar, biodegradabilitas, dan biokompatibilitas yang menjadikannya sebagai polimer yang berpotensi untuk aplikasi biomedis ${ }^{[4,9]}$.

\section{Pektin}

Pektin merupakan salah satu polimer polisakarida yang telah dipelajari secara umum dalam industri makanan dan farmasi untuk perlindungan dan pelepasan zat aktif (obat dan vitamin) yang terkontrol, karena sifatnya biokompatibilitas yang sangat baik, sensitivitas $\mathrm{pH}$, biodegradabilitas, dan non toksisitas ${ }^{[2,8]}$. Selain itu, pektin telah digunakan dalam industri makanan untuk waktu yang lama karena sifat gel, pengental dan emulsifikasi, serta telah teruji keamanannya bagi tubuh manusia ${ }^{[16,47]}$. Pektin dengan derajat esterifikasi rendah dapat membentuk gel dengan ion logam divalen termasuk $\mathrm{Ca}^{2+}$ dan $\mathrm{Zn}^{2+}$ dalam larutan asam. Sifat tersebut, secara signifikan dapat memperpanjang pelepasan obat dari matriks berbasis pektin ${ }^{[16]}$. Pektin adalah golongan polisakarida kompleks di mana asam D-galakturonat terikat dengan a-1,4glikosidik $^{[16,48]}$.

Zat aktif yang berhasil dienkapsulasi oleh pektin yaitu asam folat ${ }^{[2,8]}$ dan natrium dikofenak ${ }^{[16,17]}$. Penggunaan pektin untuk enkapsulasi lebih efektif dilakukan dengan kombinasi polimer lain, seperti alginat ${ }^{[2,8]}$ dan kitosan ${ }^{[17]}$. Pektin kombinasi dengan alginat menghasilkan mikropartikel yang lebih kuat, karena kemungkinan besar kekuatan dan stabilitas pektin lebih tinggi dibandingkan dengan alginat. alginat-pektin untuk enkapsulasi asam folat memberikan pelepasan terkontrol dengan pelepasan jauh lebih rendah pada $\mathrm{pH} 1,2$ dibandingkan pada $\mathrm{pH} 8,2^{[8]}$. Hal ini dapat dikaitkan oleh fakta bahwa gugus asam karboksilat alginat sebagian besar tetap tidak terdisosiasi dengan nilai pKa dari gugus guluronat dan manuronat masing-masing adalah 3,2 dan 4, serta relaksasi polimer jauh berkurang karena ikatan hidrogen internal[6,8], dan pektin menunjukkan gelasi yang diinduksi asam karena pembentukan ikatan hidrogen pada 
kondisi $\mathrm{pH}$ lebih asam dari 3 yang menjelaskan pelepasan asam folat tidak ada atau diabaikan pada $\mathrm{pH} 2^{[8,49]}$. Selain itu, pektin kombinasi dengan kitosan telah dilakukan untuk enkapsulasi natrium diklofenak ${ }^{[17]}$, yang menunjukkan penambahan konsentrasi kitosan dapat meningkatkan efisiensi enkapsulasi obat.

\section{Enkapsulasi Zat Aktif dengan Perbedaan Keasaman}

Obat merupakan suatu zat aktif yang bersifat asam atau basa, serta memiliki efek terapeutik untuk kelangsungan kesembuhan dari penyakit. Beberapa zat aktif memiliki stabilitas yang rendah dan pelepasan obat yang kurang terkontrol, seperti asam folat yang mudah terdegradasi dalam kondisi asam ${ }^{[2]}$, asam askorbat yang sensitif terhadap suhu dan oksigen menyebabkannya terdegradasi cepat ${ }^{[3,4]}$, serta teofilin yang memerlukan perpanjangan pelepasan obat ${ }^{[5]}$. Namun hal ini dapat diatasi dengan teknik enkapsulasi zat aktif menggunakan polimer yang bersifat biodegradable. Salah satu polimer yang banyak digunakan untuk teknik enkapsulasi adalah polimer golongan polisakarida, seperti alginat, kitosan, selulosa, pektin, dan turunannya telah berhasil untuk enkapsulasi zat aktif yang bersifat asam, seperti asam folat, asam askorbat, vankomisin, amoksisilin, siprofloksasin, sefaleksin, parasetamol, tiamin, meropenem, dan doksisiklin (dapat dilihat pada Tabel 2), dan bersifat basa, seperti teofilin, klotrimazol, dan natrium dikofenak (dapat dilihat pada Tabel 3). Enkapsulasi zat aktif telah menghasilkan banyak sifat penting seperti penghantaran obat lambat atau terkontrol, peningkatan stabilitas, dan peningkatan bioavailabilitas sehingga meningkatkan kesesuaian untuk aplikasinya ${ }^{[8]}$.

Berdasarkan Tabel 2 dan 3, perbedaan sifat keasaman zat aktif mempengaruhi efisiensi enkapsulasi. Zat aktif yang bersifat asam cenderung memiliki efisiensi enkapsulasi lebih tinggi daripada zat aktif bersifat basa yang telah berhasil dienkapsulasi oleh polimer polisakarida. Namun, tidak memberikan perbedaan pelepasan obat pada kondisi cairan lambung $(\mathrm{pH} 1,2)$ dan cairan usus halus $(\mathrm{pH} 7,4)$. Zat aktif bersifat asam dan basa dalam kebanyakan studi yang telah dilakukan, sama-sama memiliki pelepasan obat tertinggi pada kondisi basa.

\section{Zat aktif bersifat asam}

Beberapa zat aktif bersifat asam telah berhasil dienkapsulasi oleh polimer golongan polisakarida diantaranya asam folat ${ }^{[8]}$, asam askorbat ${ }^{[3,4,9]}$, amoksisilin ${ }^{[10,33]}$, vankomisin $^{[10,11,19]}$, siprofloksasin ${ }^{[10,25]}$, parasetamo[ ${ }^{[12]}$, sefaleksin ${ }^{[13,14]}$, tiamin ${ }^{[50]}$, meropenem $^{[30]}$, dan doksisiklin ${ }^{[35]}$ yang menunjukkan efisiensi enkapsulasi berbeda. Efisiensi enkapsulasi tertinggi mencapai 95\% diperoleh dari enkapsulasi amoksisilin dengan kitosan-pektin, dengan menggunakan kombinasi polimer yang sama efisiensi enkapsulasi dari vankomisin dan siprofloksasin mencapai $92 \%$ dan $91 \%{ }^{[10]}$. Nilai efisiensi enkapsulasi dipengaruhi oleh beberapa faktor seperti konsentrasi polimer dan zat aktif, kondisi $\mathrm{pH}$, ukuran partikel, dan interaksi elektrostatik antarpolimer atau antara polimer dengan zat aktif. 
Tabel 2. Beberapa enkapsulasi zat aktif bersifat asam menggunakan polimer polisakarida

\begin{tabular}{|c|c|c|c|c|}
\hline Zat aktif & $\begin{array}{c}\text { Polimer } \\
\text { polisakarida }\end{array}$ & $\begin{array}{c}\text { Efisiensi } \\
\text { enkapsulasi (EE) } \\
\text { dan drug loading (DL) }\end{array}$ & Pelepasan obat & Ref. \\
\hline $\begin{array}{l}\text { Asam folat } \\
\text { (vitamin B9) }\end{array}$ & $\begin{array}{l}\text { Alginat/Pektin } \\
\text { (sistem } \\
\text { nanopratikel) }\end{array}$ & $\begin{array}{l}\mathrm{EE}=44-92 \% \\
\mathrm{DL}=0,4-0,9 \%\end{array}$ & $\begin{array}{l}\text { Studi pelepasan obat dalam larutan buffer } \\
\text { pada pH } 2 \text { tidak menunjukkan pelepasan, pada } \\
\text { pH } 6 \text { pelepasan mencapai } 80-86 \% \text {, dan pada } \\
\text { pH } 7,4 \text {, pelepasan mencapai } 50-86 \% \text {. }\end{array}$ & {$[8]$} \\
\hline \multirow[t]{3}{*}{$\begin{array}{l}\text { Asam askorbat } \\
\text { (vitamin C) }\end{array}$} & $\begin{array}{l}\text { Ca-alginat } \\
\text { (sistem hidrogel) }\end{array}$ & $E E=74,5 \%$ & $\begin{array}{l}\text { Studi pelepasan obat dalam larutan buffer } \mathrm{pH} \\
5,8 \text { menunjukkan pelepasan kumulatif sekitar } \\
47,1 \% \text { hingga } 24 \text { jam. }\end{array}$ & [3] \\
\hline & $\begin{array}{l}\text { Nanokristal } \\
\text { selulosa/ } \\
\text { oligosakarida } \\
\text { kitosan }\end{array}$ & $\begin{array}{l}\text { EE pada: } \\
\text { pH } 3=71.6 \% \text { dan } \\
\text { pH } 5=91.0 \% \\
\text { DL pada: } \\
\text { pH } 3=28.6 \% \text { dan }\end{array}$ & $\begin{array}{l}\text { Studi pelepasan obat dalam larutan phosphate } \\
\text { buffer saline (PBS) pH } 7,4 \text { menunjukkan profil } \\
\text { pelepasan yang dimuat pada media pH } 5 \text { lebih } \\
\text { terkontrol dan persentase pelepasan yang } \\
\text { lebih tinggi daripada media pH } 3 \text {, masing- } \\
\text { masing yaitu } 15 \% \text { dan } 10 \% \text {. }\end{array}$ & [4] \\
\hline & $\begin{array}{l}\text { Nanokristal } \\
\text { selulosal } \\
\text { nanoparikel } \\
\text { kitosan }\end{array}$ & $\begin{array}{l}\mathrm{pH} 5=38.4 \% \\
\mathrm{EE}=90.3 \%\end{array}$ & $\begin{array}{l}\text { Studi pelepasan obat dalam simulasi kondisi } \\
\text { pencernaan: } \\
\text { Usus halus }(\mathrm{pH} 5)<\text { duodenum }(\mathrm{pH} 7,4)< \\
\text { perut bawah }(\mathrm{pH} 2)<\text { perut atas }(\mathrm{pH} 5)\end{array}$ & [9] \\
\hline \multirow[t]{2}{*}{ Amoksisilin } & $\begin{array}{l}\text { Kitosan/alginat } \\
\text { (sistem hidrogel) }\end{array}$ & $E E=95 \%$ & - & [10] \\
\hline & $\begin{array}{l}\text { Sodium } \\
\text { alginat/kitosan } \\
\text { (sistem } \\
\text { mikropartikel) }\end{array}$ & $\begin{array}{l}\mathrm{EE}=52-92 \% \\
\mathrm{DL}=5-11 \%\end{array}$ & $\begin{array}{l}\text { Studi pelepasan obat dalam simulasi kondisi } \\
\text { cairan lambung }(\mathrm{pH} 1,2) \text { menunjukkan } \\
\text { pelepasan diperpanjang dari } 1-8 \text { jam dengan } \\
\text { pelepasan } 41 \% \text {. }\end{array}$ & [33] \\
\hline \multirow[t]{3}{*}{ Vankomisin } & $\begin{array}{l}\text { Kitosan/alginat } \\
\text { (sistem hidrogel) }\end{array}$ & $\mathrm{EE}=92 \%$ & - & [10] \\
\hline & $\begin{array}{l}\text { Kitosan (sistem } \\
\text { mikro dan } \\
\text { nanopartikel) }\end{array}$ & $\begin{array}{l}\mathrm{EE}(\text { mikro })=7-12 \% \\
\mathrm{DL}(\text { mikro })=21-30 \% \\
\mathrm{EE} \mathrm{(nano)}=32-76 \% \\
\mathrm{DL}(\text { nano })=54-91 \%\end{array}$ & $\begin{array}{l}\text { Studi pelepasan obat dari sistem mikro dan } \\
\text { nanopartikel dalam larutan } \mathrm{pH} 1,2 \text { dan } 7,4 \\
\text { menunjukkan bahwa pelepasan tertinggi } \\
\text { diperoleh dari sistem mikro, dan pada } \mathrm{pH} 1,2 \\
\text { menunjukkan pelepasan terbatas, serta } \\
\text { pelepasan lebih tinggi pada } \mathrm{pH} 7,4 \text {. }\end{array}$ & [11] \\
\hline & $\begin{array}{l}\text { Kitosan/ } \\
\text { karboksimetil } \\
\text { selulosa (sistem } \\
\text { mikropartikel) }\end{array}$ & $\begin{array}{l}\mathrm{EE}=65-79 \% \\
\mathrm{DL}=17-38 \%\end{array}$ & $\begin{array}{l}\text { Studi pelepasan obat dalam larutan } \mathrm{PBS} \text { pH } \\
1,2 \text { dan } 7,4 \text { selama } 6 \text { jam menunjukkan } \\
\text { pelepasan tertinggi pada } \mathrm{pH} 7,4 \text {. }\end{array}$ & [19] \\
\hline \multirow[t]{2}{*}{ Siprofloksasin } & $\begin{array}{l}\text { Kitosan/alginat } \\
\text { (sistem hidrogel) }\end{array}$ & $\mathrm{EE}=91 \%$ & - & {$[10]$} \\
\hline & $\begin{array}{l}\text { Xanthan } \\
\text { gum/kitosan } \\
\text { (sistem hidrogel) }\end{array}$ & $\mathrm{EE}=93,8 \%$ & $\begin{array}{l}\text { Studi pelepasan dalam larutan PBS pH } 7,4 \\
\text { menunjukkan peningkatan yang stabil dalam } \\
\text { pelepasan obat kumulatif dengan jumlah } \\
\text { pelepasan tertinggi mencapai sekitar } 96,1 \% \\
\text { hingga } 150 \text { menit. }\end{array}$ & [25] \\
\hline
\end{tabular}




\begin{tabular}{|c|c|c|c|c|}
\hline Zat aktif & $\begin{array}{c}\text { Polimer } \\
\text { polisakarida }\end{array}$ & $\begin{array}{c}\text { Efisiensi } \\
\text { enkapsulasi (EE) } \\
\text { dan drug loading } \\
\text { (DL) }\end{array}$ & Pelepasan obat & $\begin{array}{c}\text { Ref } \\
\text {. }\end{array}$ \\
\hline Parasetamol & $\begin{array}{l}\text { Kitosan/alginat } \\
\text { (sistem } \\
\text { mikroenkapsul } \\
\text { asi) }\end{array}$ & $E E=50-76 \%$ & $\begin{array}{l}\text { Studi pelepasan obat dalam larutan } \\
\text { buffer } \mathrm{HCl}(\mathrm{pH} 1,2) \text { dan buffer fosfat }(\mathrm{pH} \\
6,8) \text { menunjukkan pelepasan yang } \\
\text { berkepanjangan dan pelepasan obat } \\
\text { yang bergantung pada } \mathrm{pH} \text { dimana } \\
\text { persentase obat yang dilepaskan dalam } \\
\text { media asam cukup rendah dan sebagian } \\
\text { besar pelepasan obat terjadi pada } \\
\text { kondisi basa. }\end{array}$ & {$[12]$} \\
\hline \multirow[t]{2}{*}{ Sefaleksin } & $\begin{array}{l}\text { Karboksimetil } \\
\text { selulosa } \\
\text { (sistem } \\
\text { nanohibrid) }\end{array}$ & $E E=83 \%$ & $\begin{array}{l}\text { Studi pelepasan obat dalam simulasi } \\
\text { kondisi pencernaan pada } \mathrm{pH} 1,2 \\
\text { pelepasan rendah selama } 2 \text { jam sekitar } \\
<10 \% \text {, pH } 6,8 \text { selama } 2 \text { jam pelepasan } \\
\text { mencapai sekitar } 60 \% \text {, dan } \mathrm{pH} 7,4 \\
\text { selama } 4 \text { jam pelepasan mencapai } \\
\text { sekitar } 92 \% \text {. }\end{array}$ & [13] \\
\hline & $\begin{array}{l}\text { Mikrokristal } \\
\text { selulosa } \\
\text { (sistem } \\
\text { hidrogel) }\end{array}$ & $\mathrm{DL}=19-26 \%$ & $\begin{array}{l}\text { Studi pelepasan obat pada kondisi pH } \\
\text { yang berbeda, yaitu pada } \mathrm{pH} 1,2 \\
\text { mencapai sekitar } 14-16 \% \text {, pH } 6,8 \\
\text { mencapai sekitar } 83-87 \% \text {, dan } \mathrm{pH} 7,4 \\
\text { mencapai sekitar } 87-98 \% \text {. }\end{array}$ & [14] \\
\hline $\begin{array}{l}\text { Tiamin } \\
\text { (vitamin B1) }\end{array}$ & $\begin{array}{l}\text { Kitosan } \\
\text { (sistem } \\
\text { nanopartikel) }\end{array}$ & $E E=90 \%$ & - & [50] \\
\hline Meropenem & $\begin{array}{l}\text { Kitosan } \\
\text { (sistem } \\
\text { nanopartikel) }\end{array}$ & $E E=71,5-76,3 \%$ & $\begin{array}{l}\text { Studi pelepasan obat dalam larutan PBS } \\
\text { pH } 7,4 \text { menunjukkan pelepasan ledakan } \\
\text { awal selama } 2 \text { jam pertama dan diikuti } \\
\text { pola pelepasan berkelanjutan, pelepasan } \\
\text { mencapai sekitar } 60-70 \% \text {. }\end{array}$ & [30] \\
\hline Doksisiklin & $\begin{array}{l}\text { Kitosan/karbok } \\
\text { simetil kitosan } \\
\text { (sistem } \\
\text { nanopartikel) }\end{array}$ & $\begin{array}{l}E E=75 \% \\
D L=28 \%\end{array}$ & - & [35] \\
\hline
\end{tabular}


Tabel 3. Beberapa enkapsulasi zat aktif bersifat basa menggunakan polimer polisakarida

\begin{tabular}{|c|c|c|c|c|}
\hline Zat aktif & $\begin{array}{l}\text { Polimer } \\
\text { polisakarida }\end{array}$ & $\begin{array}{c}\text { Efisiensi } \\
\text { enkapsulasi (EE) } \\
\text { dan drug loading } \\
\text { (DL) }\end{array}$ & Pelepasan obat & Ref. \\
\hline \multirow[t]{5}{*}{ Teofilin } & $\begin{array}{l}\text { Natrium alginat } \\
\text { (sistem hidrogel) }\end{array}$ & $\begin{array}{l}\mathrm{EE}=43,22- \\
72,25 \%\end{array}$ & $\begin{array}{l}\text { Studi pelepasan obat dalam larutan } \\
\text { buffer pH 1,2 selama } 2 \text { jam pertama } \\
\text { mencapai sekitar } 5-15 \% \text { dan dilanjutkan } \\
\text { dalam larutan buffer } \mathrm{pH} 7,4 \text { pelepasan } \\
\text { mencapai }>90 \% \text { selama } 11 \text { jam. }\end{array}$ & [5] \\
\hline & $\begin{array}{l}\text { Kitosan (sistem } \\
\text { hidrogel) }\end{array}$ & $\begin{array}{c}\text { EE pada: } \\
\text { pH } 1,5=41,6 \% \\
\text { pH } 7,5=70,45 \% \\
\text { DL pada: } \\
\text { pH } 1,5=14,72 \% \\
\text { pH } 7,5=26,51 \%\end{array}$ & $\begin{array}{l}\text { Studi pelepasan obat jauh lebih cepat } \\
\text { pada kondisi } \mathrm{pH} 7,6 \text { daripada } \mathrm{pH} 1,5 \text {. }\end{array}$ & [15] \\
\hline & $\begin{array}{l}\text { N-suksinil kitosan- } \\
\text { g-poli (asam } \\
\text { akrilat) (sistem } \\
\text { hidrogel) }\end{array}$ & $\begin{array}{l}E E=62-91 \% \\
D L=15,5-22,8 \%\end{array}$ & $\begin{array}{l}\text { Studi pelepasan obat dalam simulasi } \\
\text { cairan lambung }(\mathrm{pH} 1,2) \text { mencapai } 7,4 \\
-14,9 \% \text { dan simulasi cairan usus }(\mathrm{pH} \\
7,4) \text { mencapai } 51-92 \% \text {. }\end{array}$ & [34] \\
\hline & $\begin{array}{l}\mathrm{N} \text {-suksinil kitosan- } \\
\text { g-poli (asam } \\
\text { metakrilat) (sistem } \\
\text { hidrogel) }\end{array}$ & $\begin{array}{l}E E=58-94 \% \\
D L=14.5-23,5 \%\end{array}$ & $\begin{array}{l}\text { Studi pelepasan obat dalam simulasi } \\
\text { cairan lambung }(\mathrm{pH} 1,2) \text { mencapai } \\
<13 \% \text { dan simulasi cairan usus }(\mathrm{pH} 7,4) \\
\text { mencapai } 90 \% \text {. }\end{array}$ & [32] \\
\hline & $\begin{array}{l}\text { Kalsium/kitosan } \\
\text { termodifikasi } \\
\text { (sistem mikrosfer) }\end{array}$ & $\begin{array}{l}E E=69.61 \% \\
D L=53.40 \%\end{array}$ & $\begin{array}{l}\text { Studi pelepasan obat dalam larutan } \mathrm{HCl} \\
(\mathrm{pH} 1) \text { dan PBS }(\mathrm{pH} 7,4) \text { masing- } \\
\text { masing mencapai pelepasan sekitar } \\
\text { sekitar } 75 \% \text { and } 65 \% \text { selama } 12 \text { jam. }\end{array}$ & [51] \\
\hline Klotrimazol & $\begin{array}{l}\text { Kitosan (sistem } \\
\text { mikrokapsul) }\end{array}$ & $\begin{array}{l}E E=56,66- \\
93,82 \%\end{array}$ & $\begin{array}{l}\text { Studi pelepasan obat dalam larutan } \\
\text { buffer fosfat pH } 5,5 ; 7 \text {; dan } 8 \\
\text { menunjukkan pelepasan obat lebih } \\
\text { tinggi pada pH } 5,5 \text { mencapai } 66,1 \% \\
\text { setelah } 12 \text { jam. }\end{array}$ & [21] \\
\hline $\begin{array}{l}\text { Natrium } \\
\text { diklofenak }\end{array}$ & Pektin & $\begin{array}{l}\mathrm{EE}=35-79 \% \\
\mathrm{DL}=7-8 \%\end{array}$ & $\begin{array}{l}\text { Pelepasan obat dalam simulasi cairan } \\
\text { lambung }(\mathrm{pH} 1,2) \text { mencapai } 3,04 \% \text {, } \\
\text { dalam simulasi cairan usus halus }(\mathrm{pH} \\
6,8) \text { mencapai } 3,66 \% \text {, dan simulasi } \\
\text { cairan usus besar ( } \mathrm{pH} 7,4) \text { mencapai } \\
79,43 \% \text {. }\end{array}$ & [16] \\
\hline
\end{tabular}




\begin{tabular}{|c|c|c|c|c|}
\hline Zat aktif & $\begin{array}{c}\text { Polimer } \\
\text { polisakarida }\end{array}$ & $\begin{array}{c}\text { Efisiensi } \\
\text { enkapsulasi (EE) } \\
\text { dan drug loading } \\
\text { (DL) }\end{array}$ & Pelepasan obat & Ref. \\
\hline & $\begin{array}{l}\text { Pektin/kitosan } \\
\text { (sistem } \\
\text { nanopartikel) }\end{array}$ & $\begin{array}{l}\mathrm{EE}=60,6-99,50 \% \\
\mathrm{DL}=28,97-68,65 \%\end{array}$ & $\begin{array}{l}\text { Studi pelepasan obat dalam simulasi cairan } \\
\text { lambung (pH 1,2) selama } 2 \text { jam pertama } \\
\text { menunjukkan pelepasan yang sangat } \\
\text { rendah }(0,02 \% \text { dari obat yang dimuat), } \\
\text { dilanjutkan pada simulasi cairan usus } \\
\text { halus ( } \mathrm{pH} 6,8) \text { mencapai } 69 \% \text { obat dilepas } \\
\text { selama } 3 \text { jam, dan obat yang tersisa }(30 \%) \\
\text { dilepas pada kondisi cairan usus besar }(\mathrm{pH} \\
5,5) \text { selama } 55 \text { jam pada tingkat pelepasan } \\
\text { lebih rendah. Sedangkan pada studi } \\
\text { pelepasan obat dalam larutan buffer pH } \\
7,4 \text { mencapai } 97 \% \text { selama } 12 \text { jam. }\end{array}$ & {$[17]$} \\
\hline & $\begin{array}{l}\text { Kitosan (sistem } \\
\text { nanopartikel }\end{array}$ & $\mathrm{EE}=29,3-31,1 \%$ & $\begin{array}{l}\text { Studi pelepasan obat dalam larutan buffer } \\
\text { fosta pH } 7,4 \text { menunjukkan pelepasan awal } \\
\text { yang cepat } 20-70 \% \text { dalam } 0,5 \text { jam dan } \\
\text { diikuti pelepasan lambat dalam } 8 \text { jam. }\end{array}$ & [20] \\
\hline & $\begin{array}{l}\text { Kitosan (sistem } \\
\text { hidrogel) }\end{array}$ & $\mathrm{EE}=64-85 \%$ & $\begin{array}{l}\text { Studi pelepasan obat dalam larutan PBS } \\
(\mathrm{pH} 7,4) \text { selama } 130 \text { menit menujukkan } \\
\text { pelepasan obat mencapat }>90 \% \text {. }\end{array}$ & [22] \\
\hline & $\begin{array}{l}\text { Karboksimetil } \\
\text { selulosa/kitosan } \\
\text { (sistem hidrogel) }\end{array}$ & $\begin{array}{l}\mathrm{EE}=56-65 \% \\
\mathrm{DL}=42-47 \%\end{array}$ & $\begin{array}{l}\text { Pelepasan obat kumulatif } 40 \% \text { pada } \mathrm{pH} \\
1,2 \text { (simulasi cairan lambung) selama } 2 \\
\text { jam dan dilanjut pada pH } 6,8 \text { (simulasi } \\
\text { cairan usus) selama } 32 \text { jam menunjukkan } \\
\text { pelepasan kumulatif mencapai sekitar } \\
79 \% \text {. }\end{array}$ & [23] \\
\hline
\end{tabular}


Efisiensi enkapsulasi meningkat secara signifikan dengan penambahan konsentrasi kitosan BM tinggi dan kitosan BM rendah. Namun, kitosan BM rendah tidak memberikan pengaruh yang signifikan terhadap peningkatan efisiensi enkapsulasi parasetamo|[12]. Konsentrasi kombinasi polimer juga berperan dalam peningkaan efisiensi enkapsulasi. Pada studi enkapsulasi dengan kitosan-CMC rasio 3:1 dan 1:3 menunjukkan efisiensi enkapsulasi vankomisin lebih tinggi dibandingkan rasio 1:1, karena vankomisin yang mampu berinteraksi dengan kelebihan kitosan dan CMC. Rasio 1:3 kitosan-CMC memberikan efisiensi enkapsulasi paling tinggi, kemungkinan karena kemampuan zat aktif untuk berinteraksi dengan muatan negatif bebas $\mathrm{CMC}{ }^{[19]}$. Selain itu, adanya interaksi elekstrostatik antarpolimer atau polimer dengan zat aktif yang mempengaruhi efisiensi enkapsulasi. Efisiensi enkapsulasi meningkat karena muatan zwitterionik meropenem yang memungkinkan interaksi ionik dengan gugus amina kitosan ${ }^{[30]}$. Adanya interaksi elektrostatik antara gugus amina kitosan yang bermuatan positif dan gugus karboksil alginat yang bermuatan negatif menghasilkan kompleks alginat-kitosan yang membentuk membran kompleks polielektrolit pada permukaan matriks yang dapat mengurangi difusi zat aktif, serta kepadatan ikatan silang mengakibatkan ketebalan dan kekuatan membran kitosan meningkat secara signifikan pada konsentrasi yang lebih tinggi, hal ini mengarahkan pada peningkatan efisiensi enkapsulasi parasetamo|[12]. Selain itu, peningkatan konsentrasi obat juga meningkatkan efsiensi enkapsulasi dan drug loading siprofloksasin ${ }^{[25]}$.

Efisiensi enkapsulasi pada studi kondisi $\mathrm{pH}$ gelasi yang berbeda, nilai efisiensi enkapsulasi parasetamol meningkat dengan peningkatan $\mathrm{pH}$, namun tidak menunjukkan efek yang signifikan. Selain itu, studi pada kondisi waktu gelasi yang berbeda menunjukkan pengaruh yang signifikan terhadap efisiensi enkapsulasi. Meningkatkan waktu gelasi mengurangi efisiensi enkapsulasi parasetamol dari 33,92\% pada waktu gelasi 10 menit hingga terendah $5 \%$ pada 60 menit ${ }^{[12]}$. Studi pada kondisi $\mathrm{pH}$ media juga dilakukan pada asam askorbat pada $\mathrm{pH} 3$ dan 5. Asam askorbat memiliki pKa utama 4,2 sehingga pada media $\mathrm{pH} 5$ gugus hidroksil asam askorbat mengalami deprotonasi menghasilkan interaksi elektrostatik antara kitosan-selulosa bermuatan positif dengan asam askrobat bermuatan negatif, yang mengarahkan pada efisiensi enkapsulasi dan drug loading yang lebih tinggi[4]. Hal ini juga dinyatakan oleh Baek dkk (2021), bahwa asam askorbat terionisasi sebagian pada pH netral, menghasilkan muatan negatif yang akan mengikat kitosan, menghasilkan efisiensi enkapsulasi yang lebih tinggi[i]. Selain itu, ukuran partikel juga mempengaruhi efisiensi enkapsulasi, seperti yang dilaporkan oleh Cerchira dkk (2015), bahwa enkapsulasi vankomisin dalam mikro dan nanopartikel kitosan menunjukkan efisiensi enkapsulasi tertinggi pada enkapsulasi dengan nanopartikel kitosan ${ }^{[11]}$. 
Studi pelepasan obat berdasarkan Tabel 2, enkapsulasi zat aktif bersifat asam menunjukkan pelepasan tertinggi pada media atau kondisi basa. Enkapsulasi dengan kitosan-alginat dapat meningkatkan pelepasan obat yang berkepanjangan yang berpengaruh pada pelepasan parasetamol yang bergantung pada $\mathrm{pH}$, menunjukkan pelepasan obat dalam media asam cukup rendah dan sebagian besar pelepasan obat terjadi pada kondisi basa[12]. Asam folat yang dienkapsulasi oleh alginat-pektin juga tidak menunjukkan pelepasan obat pada media asam, karena berdasarkan fakta bahwa gugus asam karboksilat alginat sebagian besar tetap tidak terpisahkan dengan nilai pKa 3,2 dan 4 dari gugus guluron dan mannuronat masing-masingnya, dan relaksasi polimer jauh berkurang karena ikatan hidrogen internal. Selain itu, pektin menunjukkan gelasi yang diinduksi asam karena pembentukan ikatan hidrogen pada kondisi $\mathrm{pH}$ lebih asam dari 3 yang menjelaskan tidak ada atau dapat diabaikannya pelepasan asam folat yang diamati pada $\mathrm{pH} 2$, dan asam folat sebagian besar tetap tidak terdisosiasi pada $\mathrm{pH} 2^{[8]}$. Sefaleksin (SF) juga menunjukkan pelepasan obat yang rendah pada $\mathrm{pH} 1,2$ dan pelepasan obat tertinggi pada $\mathrm{pH}>6,8$. Hal ini dapat dikaitkan dengan keberadaan obat dalam berbagai bentuk yaitu kation $\left(\mathrm{H}_{2} \mathrm{SF}^{+}\right)$, zwitterion ( $\left.\mathrm{HSF}^{-}\right)$dan anion (SF-). Bentuk zwitterion dari sefaleksin mendominasi dalam kisaran $\mathrm{pH} 2,56-6,88$, sefaleksin adalah anionik di atas $\mathrm{pH} 6,88$ dan kationik di bawah 2,56. Di bawah $\mathrm{pH} 2,56$, obat ada dalam bentuk kationik dengan kelebihan ion $\mathrm{H}^{+}$untuk memprotonasi gugus hidroksil yang meniadakan tolakan elekstrostatik yang rendah menyebabkan jumlah pelepasan obat yang rendah pada media $\mathrm{pH} \mathrm{1,2} \mathrm{(cairan} \mathrm{lambung).} \mathrm{Namun,} \mathrm{dalam} \mathrm{bentuk} \mathrm{zwitterion,}$ obat menunjukkan sifat asam dan basa. Oleh karena itu, dapat bergabung dengan ion logam dan ion $\mathrm{H}^{+}$dalam media $\mathrm{pH} \mathrm{6,8}$ (cairan usus), menghasilkan pelepasan obat yang lebih tinggi. Selanjutnya, dalam bentuk anionik, sefaleksin dapat mengikat dengan ion logam yang tersedia dalam larutan buffer $(\mathrm{pH} \mathrm{7,4)}$ yang menyebabkan pelepasan obat lebih tinggi daripada pelepasan pada $\mathrm{pH} 6,8^{[14]}$.

Pelepasan obat juga dikaitkan dengan sifat penyerapan air dan proses peparasi. Pelepasan vankomisin yang tinggi karena semakin tingginya penyerapan air, dan pelepasan vankomisin dari hasil peparasi freeze-dried lebih rendah daripada dari spraydried pada $\mathrm{pH}$ 2,0 dan $\mathrm{pH}$ 7,4 yang dapat dikaitkan dengan kemampuan yang lebih rendah untuk menyerap air ${ }^{[11]}$. Selain itu, vankomisin yang dienkapsulasi oleh kitosan$\mathrm{CMC}$ rasio 1:3 pada kondisi $\mathrm{pH} 7,4$ menunjukkan pelepasan obat lebih tinggi daripada rasio $1: 1$ dan 3:1, pelepasan ini dapat dikaitkan dengan sifat penyerapan air, semakin tinggi penyerapan air maka semakin tinggi pelepasan obat dari formulasi ${ }^{[19]}$. Selain itu, dalam studi pelepasan asam askorbat yang dibuat pada media $\mathrm{pH} 5$ menunjukkan pelepasan lebih terkontrol daripada dibuat pada media $\mathrm{pH} 3$, Karena hasil drug loading yang lebih tinggi menghasilkan gradien konsentrasi yang lebih tinggi dan difusi yang lebih cepat ${ }^{[4]}$. 
Zat aktif dapat mengalami pelepasan ledakan awal, seperti dalam studi pelepasan meropenem bahwa pelepasan ledakan awal dialami selama 2 jam pertama yang kemudian diikuti pelepasan berkelanjutan pada jam berikutnya. Pelepasan ledakan awal mungkin dikaitkan dengan difusi molekul meropenem yang terlokalisasi pada atau dekat dengan permukaan polimer (kitosan). Pelepasan berkelanjutan kemudian terjadi karena difusi meropenem melalui matriks kitosan yang terikat silang. Pelepasan meropenem pada kecepatan yang lebih lambat atau terkontrol dipengaruhi oleh semakin tingginya konsentrasi kitosan ${ }^{[30]}$.

\section{Zat aktif bersifat basa}

Teofilin telah berhasil dienkapsulasi oleh kitosan dan turunannya ${ }^{[15,32,34,51]}$, serta alginat ${ }^{[5]}$. Enkapsulasi dengan turunan kitosan ( $\mathrm{N}$-suksinil kitosan) memberikan nilai efisiensi enkapsulasi mencapai $90 \%{ }^{[32,34]}$, daripada kitosan dan alginat. $\mathrm{pH}$ media juga mempengaruhi nilai efisiensi enkapsulasi, studi pada kondisi media basa memberikan nilai efisiensi lebih tinggi daripada media asam yaitu $70,45 \%$ dan $41,6 \%$ untuk masingmasing kondisi media ${ }^{[5]}$. Selain itu, konsentrasi polimer dan penggunaan agen pengikat silang juga mempengaruhi nilai efisiensi. Peningkatan konsentrasi polimer meningkatkan efisiensi enkapsulasi dan drug loading teofilin. Namun, konsentrasi agen pengikat silang berbanding terbalik dengan drug loading dan efisiensi enkapsulasi. Konsentrasi agen pengikat silang (seperti N,N-metilenbisakrilamida/MBA) yang lebih tinggi mendorong pembentukan jaringan hidrogel kaku yang akan menekan difusi obat, sehingga terjadinya penurunan efisiensi enkapsulasi teofilin ${ }^{[32,34]}$. Peningkatan efisiensi enkapsulasi teofilin dalam natrium alginat disebabkan oleh kelarutan yang lebih rendah dari teofilin dalam larutan pengikat silang ${ }^{[5]}$.

Natrium diklofenak juga telah berhasil dienkapsulasi oleh kitosan ${ }^{[20,22]}$, pektin ${ }^{[16]}$, kitosan-CMC (karboksilmetil selulosa) ${ }^{[23]}$, dan pektin-kitosan ${ }^{[17]}$. Efisiensi enkapsulasi natrium diklofenak tertinggi mencapai 60,6 - 99,50\% dengan pektin-kitosan ${ }^{[17]}$ dan terendah dengan kitosan mencapai $29,3-31,1 \%{ }^{[20]}$. Hal ini dapat dikaitkan dengan penambahan konsentrasi kitosan yang rendah pada pektin menghasilkan peningkatan efisiensi enkapsulasi, dan efek yang tinggi dari kitosan dan pektin terhadap efisiensi enkapsulasi yang menunjukkan interaksi pektin-kitosan dengan zat aktif ${ }^{[17]}$. Pektin memiliki gugus hidroksil yang dapat diikat silang dengan agen pengikat, seperti suksinat anhidrida dan glutarik dialdehid) menunjukkan efisiensi enkapsulasi lebih tinggi dengan menggunakan glutarik dialdehid. Hal ini dapat dijelaskan dengan tingkat kesulitan reaksi adisi nukleofilik dan hidrofilisitas struktur asetal lebih tinggi dari pada ester yang dapat menyebabkan interaksi lebih baik antara natrium diklofenak dengan pektin yang diikat silang glutarik dialdehid[16]. Berat molekul (BM) kitosan juga mempengaruhi efisiensi enkapsulasi, meningkatnya BM kitosan akan meningkatkan efisiensi enkapsulasi ${ }^{[20]}$.

Zat aktif bersifat basa lainnya yang telah berhasil dienkapsulasi oleh kitosan adalah klotrimazol yang menunjukkan efisiensi enkapsulasi sekitar 56,66-93,82\%. Efisiensi enkapsulasi yang lebih tinggi karena kitosan dapat terprotonasi dalam kondisi asam dan klotrimazol menunjukkan muatan negatif dalam larutan, serta gaya tarik elektrostatik antara ion $\mathrm{NH}_{3}{ }^{+}$dari kitosan dan muatan negatif klotrimazol dapat meningkatkan efisiensi enkapsulasi[21]. 
Berdasarkan studi pelepasan obat, profil pelepasan teofilin dan natrium diklofenak lebih tinggi pada media basa atau kondisi cairan usus halus $(\mathrm{pH}>7,4)$ (dapat dilihat pada Tabel 3), karena peningkatan konsentrasi polimer meningkatkan tolakan elektrostatik ion karboksilat dari $\mathrm{N}$-suksinil kitosan yang menyebabkan meningkatkan pelepasan teofilin ${ }^{[34]}$. Selain itu, pada kondisi asam gugus karboksil pektin dan gugus amina kitosan mengalami protonasi dan membatasi pelepasan obat yang dimuatnya ${ }^{[17]}$. Sebaliknya, pada $\mathrm{pH}>6,8$ terjadi deprotonasi gugus karboksil dari karboksimetil selulosa dan gugus amina dari kitosan yang menyebabkan pelepasan natrium diklofenak yang lebih cepat. Kelarutan natrium diklofenak yang tinggi di atas nilai pKa berkontribusi pada pelepasan obat yang lebih cepat ke dalam larutan buffer ${ }^{[23]}$. Pelepasan natrium diklofenak dari matriks pektin yang diikat silang glutarik dialdehid dipengaruhi oleh ion $-\mathrm{COOH}$ dapat menjadi - $\mathrm{COO}^{-}$di lingkungan basa. Keberadaan COO- secara signifikan meningkatkan hidrofilisitas permukaan pembawa dan berkontribusi pada pembentukan struktur pori yang mengarah pada pelepasan obat. Selain itu, ketika $-\mathrm{COOH}$ terdisosiasi menjadi - $\mathrm{COO}^{-}$, gaya tolak elektrostatik antara COO- dan anion diklofenak dapat mendorong obat ke luar dari matriks pembawa ${ }^{[16]}$. Namun, studi yang dilaporkan oleh Chen dkk (2016), menampilkan pelepasan teofilin lebih tinggi pada media asam $(\mathrm{pH} \mathrm{1,2)}$. Hal ini disebabkan oleh peningkatan kelarutan teofilin pada $\mathrm{pH}$ asam dan pelepasan obat dari partikel polimer adalah proses yang sulit, karena dipengaruhi oleh banyak faktor seperti degradasi polimer, berat molekul, kristalinitas, afinitas pengikatan antara polimer dengan obat dan sebagainya ${ }^{[51]}$. Selain itu, klotrimazol juga mengalami pelepasan obat lebih tinggi pada media $\mathrm{pH} \mathrm{5,5}$ daripada $\mathrm{pH}>7^{[21]}$. Namun, secara keseluruhan zat aktif bersifat basa dalam beberapa studi yang telah dilakukan menampilkan profil pelepasan lebih tinggi pada media basa.

\section{Kesimpulan.}

Polimer golongan polisakarida memberikan potensi yang baik untuk digunakan dalam enkapsulasi zat aktif, karena dapat meningkatkan stabilitas, bioavailabilitas, dan penghantaran obat yang terkontrol. Selain itu, sifat polimer polisakarida yang biodegradable, biokompatibilitas yang baik, dan non-toksisitas juga mendukung dalam aplikasinya. Polimer polisakarida juga memiliki sifat polikationik (dapat berinteraksi secara elektrostatik) yang memudahkan polimer untuk dimodifikasi atau dikombinasi dengan polimer lain, sehingga meningkatkan efektivitas dalam enkapsulasi zat aktif. Faktor yang dapat mempengaruhi enkapsulasi adalah konsentrasi polimer dan interaksi kimia (seperti ikatan sambung silang antarpolimer atau polimer dengan zat aktif) selama proses enkapsulasi. Selain itu, sifat keasaman zat aktif dapat mempengaruhi enkapsulasi. Zat aktif yang bersifat asam cenderung memiliki efisiensi enkapsulasi yang lebih tinggi daripada zat aktif bersifat basa. Namun, tidak memberikan perbedaan pelepasan obat pada kondisi cairan lambung $(\mathrm{pH} \mathrm{1,2)}$ dan cairan usus halus $(\mathrm{pH} 7,4)$. Zat aktif bersifat asam dan basa sama-sama memiliki pelepasan obat tertinggi pada kondisi basa. Oleh karena itu, informasi yang terangkum dalam artikel ini dapat memberikan peluang untuk studi lebih lanjut mengenai pengaruh $\mathrm{pH}$ zat aktif terhadap enkapsulasi dengan polimer yang sama, dan studi pemilihan jenis polimer polisakarida yang tepat untuk enkapsulasi zat aktif bersifat asam dan basa. 


\section{Daftar Pustaka}

1. Farmakope Indonesia Edisi VI 2020 Kementrian Kesehatan Republik Indonesia. Jakarta: Kementrian Kesehatan RI; 2020.

2. Alborzi S, Lim LT, Kakuda Y. Release of folic acid from sodium alginate-pectinpoly(ethylene oxide) electrospun fibers under invitro conditions. LWT - Food Sci Technol 2014;59(1):383-8.

3. Zhang $M$, Sun $R$, Xia $Q$. An ascorbic acid delivery system based on (W1/O/W2) double emulsions encapsulated by Ca-alginate hydrogel beads. J Drug Deliv Sci Technol 2020;60.

4. Akhlaghi SP, Berry RM, Tam KC. Modified Cellulose Nanocrystal for Vitamin C Delivery. AAPS PharmSciTech 2015;16(2):306-14.

5. Ahirrao S, Gide P, Shrivastav B, Sharma P. Extended release of theophylline through sodium alginate hydrogel beads: Effect of glycerol on entrapment efficiency, drug release. Part Sci Technol 2014;32(2):105-11.

6. Camacho DH, Uy SJY, Cabrera MJF, Lobregas MOS, Fajardo TJMC. Encapsulation of folic acid in copper-alginate hydrogels and it's slow in vitro release in physiological pH condition. Food Res Int 2019;119:15-22.

7. Tsung J, Burgess DJ. Biodegradable polymers in drug delivery systems. In: Fundamentals and Applications of Controlled Release Drug Delivery. Springer US; 2012. page 107-23.

8. Pamunuwa G, Anjalee N, Kukulewa D, Edirisinghe C, Shakoor F, Karunaratne DN. Tailoring of release properties of folic acid encapsulated nanoparticles via changing alginate and pectin composition in the matrix. Carbohydr Polym Technol Appl 2020;1:100008.

9. Baek J, Ramasamy M, Willis NC, Kim DS, Anderson WA, Tam KC. Encapsulation and controlled release of vitamin $C$ in modified cellulose nanocrystal/chitosan nanocapsules. Curr Res Food Sci 2021;4:215-23.

10. Khan YA, Ozaltin K, Bernal-Ballen A, Di Martino A. Chitosan-alginate hydrogels for simultaneous and sustained releases of ciprofloxacin, amoxicillin and vancomycin for combination therapy. J Drug Deliv Sci Technol 2021;61.

11. Cerchiara T, Abruzzo A, Di Cagno M, Bigucci F, Bauer-Brandl A, Parolin C, et al. Chitosan based micro- and nanoparticles for colon-targeted delivery of vancomycin prepared by alternative processing methods. Eur J Pharm Biopharm 2015;92:112-9.

12. 1Almurisi SH, Doolaanea AA, Akkawi ME, Chatterjee B, Sarker MZI. Taste masking of paracetamol encapsulated in chitosan-coated alginate beads. J Drug Deliv Sci Technol 2020;56.

13. Barkhordari S, Yadollahi M. Carboxymethyl cellulose capsulated layered double hydroxides/drug nanohybrids for Cephalexin oral delivery. Appl Clay Sci 2016;121122:77-85.

14. Kundu D, Banerjee T. Development of microcrystalline cellulose based hydrogels for the in vitro delivery of Cephalexin. Heliyon 2020;6(1).

15. Samanta HS, Ray SK. Controlled release of tinidazole and theophylline from chitosan based composite hydrogels. Carbohydr Polym 2014;106(1):109-20.

16. Wang S ya, Li J, Zhou Y, Li D qiang, Du G ming. Chemical cross-linking approach for prolonging diclofenac sodium release from pectin-based delivery system. Int J Biol Macromol 2019;137:512-20. 
17. Dutta RK, Sahu S. Development of diclofenac sodium loaded magnetic nanocarriers of pectin interacted with chitosan for targeted and sustained drug delivery. Colloids Surfaces B Biointerfaces 2012;97:19-26.

18. Alvarez-Lorenzo C, Blanco-Fernandez B, Puga AM, Concheiro A. Crosslinked ionic polysaccharides for stimuli-sensitive drug delivery. Adv. Drug Deliv. Rev.2013;65(9):1148-71.

19. Cerchiara T, Abruzzo A, Parolin C, Vitali B, Bigucci F, Gallucci MC, et al. Microparticles based on chitosan/carboxymethylcellulose polyelectrolyte complexes for colon delivery of vancomycin. Carbohydr Polym 2016;143:124-30.

20. Alqahtani FY, Aleanizy FS, Tahir E El, Alquadeib BT, Alsarra IA, Alanazi JS, et al. Preparation, characterization, and antibacterial activity of diclofenac-loaded chitosan nanoparticles. Saudi Pharm J 2019;27(1):82-7.

21. Yuen CWM, Yip J, Liu L, Cheuk K, Kan CW, Cheung HC, et al. Chitosan microcapsules loaded with either miconazole nitrate or clotrimazole, prepared via emulsion technique. Carbohydr Polym 2012;89(3):795-801.

22. Gull N, Khan SM, Butt OM, Islam A, Shah A, Jabeen S, et al. Inflammation targeted chitosan-based hydrogel for controlled release of diclofenac sodium. Int $\mathrm{J}$ Biol Macromol 2020;162:175-87.

23. Tan LS, Tan HL, Deekonda K, Wong YY, Muniyandy S, Hashim K, et al. Fabrication of radiation cross-linked diclofenac sodium loaded carboxymethyl sago pulp/chitosan hydrogel for enteric and sustained drug delivery. Carbohydr Polym Technol Appl 2021;2:100084.

24. Sun X, Shen J, Yu D, Ouyang X kun. Preparation of pH-sensitive Fe $3 \circ 4$ @C/carboxymethyl cellulose/chitosan composite beads for diclofenac sodium delivery. Int J Biol Macromol 2019;127:594-605.

25. Hanna DH, Saad GR. Encapsulation of ciprofloxacin within modified xanthan gumchitosan based hydrogel for drug delivery. Bioorg Chem 2019;84:115-24.

26. Tong QP, Sun HS, Wang J hua, Wang Y, Peng Y, Jiang M, et al. Preparation and characterization of Berberine Hydrochloride and Trimethoprim Chitosan/ SBE7- $\beta-C D$ microspheres. J Drug Deliv Sci Technol 2018;48(September):300-10.

27. Jing ZW, Jia YY, Wan N, Luo M, Huan ML, Kang T Bin, et al. Design and evaluation of novel $\mathrm{pH}$-sensitive ureido-conjugated chitosan/TPP nanoparticles targeted to Helicobacter pylori. Biomaterials [Internet] 2016;84:276-85. Available from: http://dx.doi.org/10.1016/j.biomaterials.2016.01.045

28. Manea YK, Khan AMT, Qashqoosh MTA, Wani AA, Shahadat M. Ciprofloxacinsupported chitosan/polyphosphate nanocomposite to bind bovine serum albumin: Its application in drug delivery. J Mol Liq [Internet] 2019;292:111337. Available from: https://doi.org/10.1016/j.molliq.2019.111337

29. Arif M, Dong QJ, Raja MA, Zeenat S, Chi Z, Liu CG. Development of novel pHsensitive thiolated chitosan/PMLA nanoparticles for amoxicillin delivery to treat Helicobacter pylori. Mater Sci Eng C 2018;83:17-24.

30. Abdelkader A, El-Mokhtar MA, Abdelkader O, Hamad MA, Elsabahy M, El-Gazayerly ON. Ultrahigh antibacterial efficacy of meropenem-loaded chitosan nanoparticles in a septic animal model. Carbohydr Polym 2017;174:1041-50.

31. Aycan D, Alemdar N. Development of pH-responsive chitosan-based hydrogel modified with bone ash for controlled release of amoxicillin. Carbohydr Polym 2018;184:401-7. 
32. Bashir S, Teo YY, Ramesh S, Ramesh K. Synthesis, characterization, properties of $\mathrm{N}$-succinyl chitosan-g-poly (methacrylic acid) hydrogels and in vitro release of theophylline. Polymer (Guildf) 2016;92:36-49.

33. Angadi SC, Manjeshwar LS, Aminabhavi TM. Novel composite blend microbeads of sodium alginate coated with chitosan for controlled release of amoxicillin. Int J Biol Macromol 2012;51(1-2):45-55.

34. Bashir S, Teo YY, Ramesh S, Ramesh K, Mushtaq MW. Rheological behavior of biodegradable $\mathrm{N}$-succinyl chitosan-g-poly (acrylic acid) hydrogels and their applications as drug carrier and in vitro theophylline release. Int $\mathrm{J}$ Biol Macromol 2018;117:454-66.

35. Xu S, Zhou Q, Jiang Z, Wang Y, Yang K, Qiu X, et al. The effect of doxycyclinecontaining chitosan/carboxymethyl chitosan nanoparticles on NLRP3 inflammasome in periodontal disease. Carbohydr Polym 2020;237.

36. Unagolla JM, Jayasuriya AC. Drug transport mechanisms and in vitro release kinetics of vancomycin encapsulated chitosan-alginate polyelectrolyte microparticles as a controlled drug delivery system. Eur J Pharm Sci 2018;114:199-209.

37. Blandón LM, Islan GA, Castro GR, Noseda MD, Thomaz-Soccol V, Soccol CR. Kefiran-alginate gel microspheres for oral delivery of ciprofloxacin. Colloids Surfaces B Biointerfaces 2016;145:706-15.

38. Azevedo MA, Bourbon Al, Vicente AA, Cerqueira MA. Alginate/chitosan nanoparticles for encapsulation and controlled release of vitamin B2. Int J Biol Macromol [Internet] 2014;71:141-6. Available from: http://dx.doi.org/10.1016/j.ijbiomac.2014.05.036

39. Ben Messaoud G, Sánchez-González L, Probst L, Jeandel C, Arab-Tehrany E, Desobry S. Physico-chemical properties of alginate/shellac aqueous-core capsules: Influence of membrane architecture on riboflavin release. Carbohydr Polym [Internet] 2016;144:428-37. Available from: http://dx.doi.org/10.1016/j.carbpol.2016.02.081

40. Abd El-Ghaffar MA, Hashem MS, El-Awady MK, Rabie AM. PH-sensitive sodium alginate hydrogels for riboflavin controlled release. Carbohydr Polym 2012;89(2):667-75.

41. Al-Kahtani AA, Sherigara BS. Controlled release of diclofenac sodium through acrylamide grafted hydroxyethyl cellulose and sodium alginate. Carbohydr Polym [Internet] 2014;104(1):151-7. Available from: http://dx.doi.org/10.1016/j.carbpol.2014.01.018

42. AL-Kahtani AA, Sherigara BS. Semi-interpenetrating network of acrylamide-graftedsodium alginate microspheres for controlled release of diclofenac sodium, preparation and characterization. Colloids Surfaces B Biointerfaces [Internet] 2014;115:132-8. Available from: http://dx.doi.org/10.1016/j.colsurfb.2013.11.040

43. Raafat Al, Kamal H, Sharada HM, Abd elhalim SA, Mohamed RD. Radiation development of gastroretentive amoxicillin trihydrate floating-alginate based beads for the treatment of helicobacter pylori. Radiat Phys Chem 2021;179.

44. Zhu H, Luo W, Ciesielski PN, Fang Z, Zhu JY, Henriksson G, et al. Wood-Derived Materials for Green Electronics, Biological Devices, and Energy Applications. Chem Rev 2016;116(16):9305-74. 
45. Yadollahi M, Gholamali I, Namazi H, Aghazadeh M. Synthesis and characterization of antibacterial carboxymethyl cellulose/ZnO nanocomposite hydrogels. Int $\mathrm{J}$ Biol Macromol [Internet] 2015;74:136-41. Available from: http://dx.doi.org/10.1016/j.ijbiomac.2014.11.032

46. Sood S, Gupta VK, Agarwal S, Dev K, Pathania D. Controlled release of antibiotic amoxicillin drug using carboxymethyl cellulose-cl-poly(lactic acid-co-itaconic acid) hydrogel [Internet]. Elsevier $\quad$ B.V.; 2017. Available from: http://dx.doi.org/10.1016/j.ijbiomac.2017.03.103

47. Lara-Espinoza C, Carvajal-Millán E, Balandrán-Quintana R, López-Franco Y, Rascón-Chu A. Pectin and pectin-based composite materials: Beyond food texture. Molecules 2018;23(4).

48. Rebitski EP, Darder M, Carraro R, Ruiz-Hitzky E. Chitosan and pectin core-shell beads encapsulating metformin-clay intercalation compounds for controlled delivery. New J Chem 2020;44(24):10102-10.

49. Yuliarti O, Hoon ALS, Chong SY. Influence of $\mathrm{pH}$, pectin and $\mathrm{Ca}$ concentration on gelation properties of low-methoxyl pectin extracted from Cyclea barbata Miers. Food Struct [Internet] 2017;11:16-23. Available from: http://dx.doi.org/10.1016/j.foostr.2016.10.005

50. Muthukrishnan S, Murugan I, Selvaraj M. Chitosan nanoparticles loaded with thiamine stimulate growth and enhances protection against wilt disease in Chickpea. Carbohydr Polym 2019;212:169-77.

51. Chen C, Zhong M, Li G, Yang F, Huang R, Xiao W, et al. Optimization on preparation conditions of calcium-crosslinked modified chitosan as potential matrix material for theophylline sustained-release beads and its evaluation of release kinetics. J Alloys Compd 2016;658:348-55. 